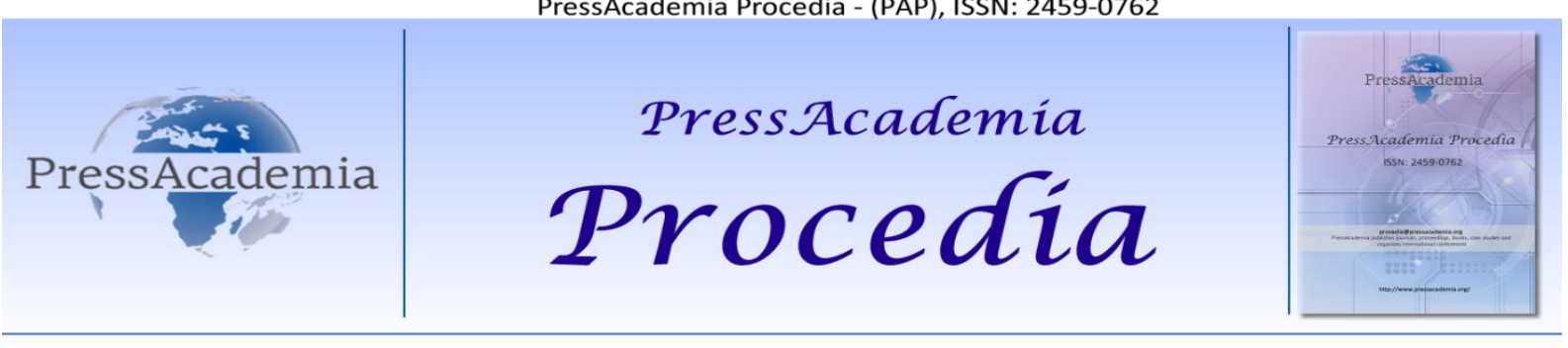

Global Business Research Congress (GBRC), May 24-25, 2017, Istanbul, Turkey

\title{
APPLICATION OF GOAL SETTING THEORY
}

\section{DOI: 10.17261/Pressacademia.2017.660 \\ PAP- GBRC-V.3-2017(86)-p.796-801}

\section{E. Serra Yurtkoru ${ }^{1}$, Tulay Bozkurt ${ }^{2}$, Fatos Bekta ${ }^{3}$, Mahir Jibril Ahmed ${ }^{4}$, Vehap Kola ${ }^{5}$ \\ ${ }^{1}$ Marmara University, Faculty of Business Administration, Istanbul, Turkey. syurtkoru@marmara.edu.tr \\ ${ }^{2}$ Marmara University, Institute of Social Sciences, Istanbul, Turkey. tulay.bozkurt@gmail.com \\ ${ }^{3}$ Marmara University, Institute of Social Sciences, Istanbul, Turkey. fatosbektash@gmail.com \\ ${ }^{4}$ Marmara University, Institute of Social Sciences, Istanbul, Turkey. directurmail@gmail.com \\ ${ }^{5}$ Marmara University, Institute of Social Sciences, Istanbul, Turkey. vehapkola@gmail.com}

To cite this document

Yurtkoru, E. S., T. Bozkurt, F. Bektas, M. J. Ahmed, V. Kola (2017). Application of goal setting theory. PressAcademia Procedia (PAP), V.3, p.796-801.

Permemant link to this document: http://doi.org/10.17261/Pressacademia.2017.660

Copyright: Published by PressAcademia and limited licenced re-use rights only.

\begin{abstract}
The purpose of this study is to test the goal theory model originally developed by Locke and Latham in organizational setting in Turkey, and explain its influence on job satisfaction and affective commitment. Also mediating role of task specific strategy and moderating role of selfefficacy are examined. Locke and Latham's goal setting measure is adapted to Turkish. Survey method is employed to collect data from 222 respondents from automotive industry. Goal setting dimensions predicted affective commitment through full mediation of job satisfaction. However task specific strategy did not have significant mediation effect and self-efficacy did not moderate but explained directly. Even though goal setting theory can be used in Turkish setting to measure job satisfaction and affective commitment, factor structure is different than the original and goal clarity is the only core goal variable. Theoretically proposed moderators and mediators are found to have partial effects or no effect at all.
\end{abstract}

Keywords: Goal setting theory, affective commitment, job satisfaction, self-efficacy, goal achievement JEL Codes: M10, L20, L21

\section{INTRODUCTION}

In today's ever-changing environment, maintaining well-motivated employees assures the attainment of business objectives. Motivated workforce is likely to remain productive and, increase organizational performance and ultimately contribute for the attainment of stakeholders' satisfaction. To enhance performance organizations set individual and organizational goals. These goals among others, serve to reinforce performance which triggers employee job satisfaction and in return increase employee organizational commitment. The purpose of this research is to examine the antecedent factors behind workers' commitment among auto industry workers in Turkey. The research sought to scrutinize the effect of goals setting practice on the workers' degree of organizational commitment, namely the affective commitment. Moreover, the research attempted to explain the mediating and moderating roles of different factors in the relation between goal setting and affective commitment.

\section{LITERATURE REVIEW}

Ever since the human relation movement, two dominant theories have been in use to investigate employees' motivation; the need-based and process-based theories which have remained in persistent competition to each other. Process-based motivational heories has come out to be powerful in explaining antecedents and consequences of motivation. 
Process-based theories have strong conceptual models that serve to predict motivation and performance. Process-based theories such as equity and expectancy theories give an expanded causes of motivation (Stecher \& Rosse, 2007). The theory clarifies how employees' expectations, needs and values, and comparisons link with job responsibilities and result motivation (Kian et al, 2014). Another process-based that is developed in the early 1970s was the goal-setting theory. The basic premises of the theory claim that a predetermined goal could serve as performance inducer. According to Locke and Latham (2006), specific goals, accompanied by challenging performance targets are likely to improve performance results as compared to simple and ambiguous goals. The setting of goal by itself gives some kind of emotional urgency, and capable to provoke energy and attention. (Locke \& Latham, 2006). The achievement of goal ultimately creates satisfaction, whereas unaccomplished goals are likely to trigger dissatisfaction, and leave stakeholders with emotional distress (Lunenburg, 2011).

Later, goal setting theory is integrated into a longitudinal high performance cycle (HPC) which provides a framework for understanding motivation more thoroughly by Latham and Locke (2007). According to HPC, goal setting theory predicts, explains, and influences an employee's job performance and satisfaction which triggers employees' commitment to organization (Latham \& Locke, 2007). Job satisfaction affects organizational commitment, and job dissatisfaction leads to reduce employee commitment to the organization. Essentially job satisfaction increases organizational commitment and high organizational commitment leads to the setting high goals, which indicates the recursive nature of HPC (Borgogni \& Dello Russo, 2012). According to high performance cycle (HPC), goal specificity and level of difficulty, which are referred to as demands, affect job performance positively. High goals lead to high performance, which in turn leads to contingent rewards, which can be external or internal, and through these, to job satisfaction. Therefore rewards mediates the role between demands and job performance (Latham \& Locke, 2007).

Relation between demands and rewards are mediated by task specific strategies. The effect of goals are dependent on the ability to discover appropriate strategies (Locke \& Latham, 2002). According to Earley and Perry (1987), when people are trained to use proper strategies, given high-performance goals, their performance improves. However, if the strategy implemented by the employees in not appropriate, then a difficult performance-outcome goal leads to worse performance than an easy goal (Early \& Perry, 1987). High performance cycle (HPC), also imposes moderators; self-efficacy being the one. Goals lead to higher performance only if people has the ability to perform the specific task required. Employees with self-efficacy find difficult goals as challenges (Bandura, 2011). Therefore self-efficacy is a moderator in the model (Seijts \& Latham, 2001). Also situational constraints which are composed of adequate financial and technical resources, organizational culture supporting goal setting, support of supervisors and a system which balances the pressure on employees to achieve complex goals and to minimize conflicting goals (Borgogoni \& Dello Russo, 2012). Based on the organizational setting theory and high performance cycle (HPC) the theoretical framework for this study is developed (See Figure 1). Only in our model the mediating role of performance on the relation between goal setting to rewards is excluded and instead goal setting is directly connected to rewards.

Figure 1. Theoretical Model

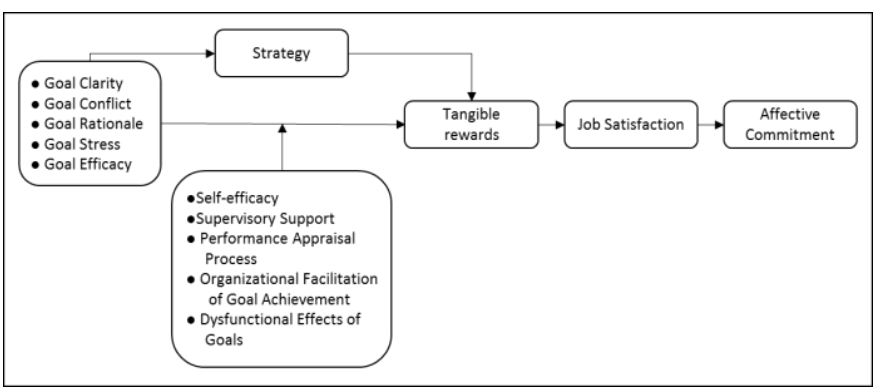

\section{DATA AND METHODOLOGY}

\subsection{Instrument}

Since the purpose of this study was to test the goal theory model developed by Locke and Latham, we used the multi-item questionnaire, the goal setting measure from Locke and Latham (1984, as cited in Lee et al., 1991). Originally the scale was 53 items however, its empirical test have revealed 51 item 10 factor measure (Lee et al., 1991). In this study we used the 51 items version and translated it into Turkish. We also measured job satisfaction, affective commitment, task specific strategy and self-efficacy items. Job satisfaction was measured by two items adapted from Borgogni and Dello Russo (2012). For measuring affective commitment Allen and Meyer's (1990) affective commitment scale was used. Task specific strategy was measured by three items (Borgogni \& Dello Russo, 2012) and to measure self-efficacy the 8 item scale by Chen, Gully, and Eden (2001) was used. All items were assessed using five-point interval scale (1=totally disagree; 5=totally agree). 


\subsection{Sampling and Data Collection}

The data for this study were collected from professionals working in managerial and non-managerial positions in automotive industry. The questionnaire was distributed to 300 professionals and with a response rate of $74 \% 222$ questionnaires were found to be appropriate for statistical analysis. The sample consisted of 68 (31.2\%) women and 150 men (68.8\%). Age of the sample ranged between 20 to 63 with a mean of 32.93 and a standard deviation of 6.58 , respondents were highly educated. The Internet sample consisted of 215 women and 167 men. Age of the sample ranged between 18 to 54 with a mean of 26.59 and a standard deviation of 6.71 , respondents were highly educated (88.9 \% university graduates).

\section{FINDINGS AND DISCUSSIONS}

First exploratory factor analyses (EFA) and reliability analyses were conducted to the scales. Kaiser-Meyer-Olkin measure of sampling adequacy and Bartlett test of sphericity tests indicated the appropriateness of data for conducting factor analyses. Principal component analysis and varimax rotation were employed to the data set. As can be seen from Table 1 goal setting measure which was originally 10 factors merged into 6 factors. Many items were eliminated from the scale either because they had loaded to more than one factor or their factor loadings were too low. Factors were named as 'performance appraisal process', 'dysfunctional effects of goals', 'organizational facilitation of goal achievement', 'supervisory support', 'goal clarity' and 'tangible rewards' as in line with literature. Then Cronbach's $\alpha$ reliability analyses were applied to measure internal consistency of the constructs. All the factors were found to be reliable (See Table 1).

Table 1: Factor Analysis and Reliability Results of Goal Setting Measure

\begin{tabular}{|c|c|c|c|}
\hline Factor Name & $\begin{array}{l}\text { Factor } \\
\text { loading }\end{array}$ & $\begin{array}{l}\text { Explained } \\
\text { variance }\end{array}$ & Reliability \\
\hline Performance Appraisal Process & & 16.43 & .88 \\
\hline $\begin{array}{l}\text { My manager makes sure that at the end of the interview I have a specific goal or goals in } \\
\text { mind that I will achieve in the future. }\end{array}$ & .75 & & \\
\hline My manager asks me if there are any areas of the job on which he or she can assist me. & .74 & & \\
\hline $\begin{array}{l}\text { My manager comes to agreement with me on steps to be taken by each of us to solve any } \\
\text { performance problems. }\end{array}$ & .73 & & \\
\hline My manager tells me what he or she thinks I have done that deserves recognition. & .72 & & \\
\hline My manager asks me to tell him/her what I have done that deserves recognition. & .71 & & \\
\hline $\begin{array}{l}\text { My manager listens openly to my explanations and concerns regarding any performance } \\
\text { problems. }\end{array}$ & .70 & & \\
\hline $\begin{array}{l}\text { If there are problems with my performance, my manager never brings up more than two of } \\
\text { them at once. }\end{array}$ & .59 & & \\
\hline My manager explains the purpose of the meeting to me. & .57 & & \\
\hline Dysfunctional Effects of Goals & & 10.37 & .75 \\
\hline $\begin{array}{l}\text { The top people here do not set a very good example for the employees since they are } \\
\text { dishonest themselves. }\end{array}$ & .74 & & \\
\hline Goals in this organization are used more to punish you than to help you do your job well. & .71 & & \\
\hline $\begin{array}{l}\text { If my boss makes a mistake that affects my ability to attain my goals, he or she refuses to } \\
\text { admit it or discuss it. }\end{array}$ & .70 & & \\
\hline My supervisor acts not supportively when I fail to reach my goals. & .66 & & \\
\hline $\begin{array}{l}\text { My boss wants me to avoid mentioning negative information or problems regarding my } \\
\text { goals or action plans. }\end{array}$ & .58 & & \\
\hline Organizational Facilitation of Goal Achievement & & 10.23 & .72 \\
\hline $\begin{array}{l}\text { The company I work for has sufficient resources (e.g. Time, money, equipment, coworkers) } \\
\text { to make goal setting work }\end{array}$ & .71 & & \\
\hline Company policies here help rather than hurt goal attainment & .65 & & \\
\hline I feel that my job training was good enough so that I am capable of reaching my job goals & .63 & & \\
\hline Work teams in this company work together to attain goals. & .62 & & \\
\hline The other people I work with encourage me to attain my goals & .56 & & \\
\hline Supervisory Support & & 9.11 & .87 \\
\hline My boss lets me participate in setting of my goals & .81 & & \\
\hline My boss is supportive with respect to encouraging me to reach my goals & .80 & & \\
\hline My boss lets me have some say in deciding how I will go about implementing my goals & .80 & & \\
\hline Goal Clarity & & 8.58 & .78 \\
\hline My boss clearly explains to me what my goals are. & .63 & & \\
\hline My boss tells me the reasons for giving me the goals I have. & .63 & & \\
\hline I have specific, clear goals to aim for on my job. & .61 & & \\
\hline I get regular feedback indicating how I am performing in relation to my goals. & .51 & & \\
\hline Tangible Rewards & & 6.53 & .79 \\
\hline
\end{tabular}


If I reach my goals, it increases my chances for a pay rise $\quad .82$

$\begin{array}{ll}\text { If I reach my goals, it increase my chances for a promotion } & .78\end{array}$

$\mathrm{KMO}=.87, \chi_{\text {Bartlett }}^{2}(351)=2609.13, \mathrm{p}=.00$

As can be seen from Table 2, all the other scales were all unidimensional. However some items from these scales were also eliminated as their factor loadings were too low and decreased the reliability of the scales. After the elimination all the scales were highly reliable.

Table 2: Scale Reliabilities

\begin{tabular}{lcc}
\hline Scale Name & Item number & Reliability \\
\hline Task Specific Strategy & 3 & .76 \\
Self-Efficacy & 6 & .83 \\
Affective Commitment & 4 & .84 \\
Job Satisfaction & 2 & .80 \\
\hline
\end{tabular}

After the prior tests, summated scores were calculated, and bivariate correlations were conducted. Later to test the research model a series of regression analyses were performed. Correlation analyses indicated all of the variables were significantly correlated however none of the correlation indicated high associations (See Table 3).

Table 3: Bivariate Correlations, Means and Standard Deviations

\begin{tabular}{|c|c|c|c|c|c|c|c|c|c|c|c|c|}
\hline Variables & Mean & SD & 1 & 2 & 3 & 4 & 5 & 6 & 7 & 8 & 9 & 10 \\
\hline 1. Performance appraisal & 3.57 & .74 & 1 & & & & & & & & & \\
\hline 2. Dysfunctional effects & 2.45 & .76 & $-.37^{* *}$ & 1 & & & & & & & & \\
\hline $\begin{array}{l}\text { 3. Organizational } \\
\text { facilitation }\end{array}$ & 3.44 & .68 & $.31 * *$ & $-.23 * *$ & 1 & & & & & & & \\
\hline 4. Supervisory support & 3.83 & .92 & $.57 * *$ & $-.38 * *$ & $.28 * *$ & 1 & & & & & & \\
\hline 5. Goal clarity & 3.45 & .78 & $.52 * *$ & $-.35 * *$ & $.58 * *$ & $.45 * *$ & 1 & & & & & \\
\hline 6. Tangible rewards & 3.34 & 1.09 & $.24 * *$ & -.13 & $.45^{* *}$ & $.18^{* *}$ & $.44^{* *}$ & 1 & & & & \\
\hline 7. Task specific strategy & 4.05 & .64 & $.25 * *$ & $-.25 * *$ & $.25 * *$ & $.27 * *$ & $.36 * *$ & $.25 * *$ & 1 & & & \\
\hline 8. Self-efficacy & 4.06 & .59 & $.32 * *$ & $-.28 * *$ & $.34 * *$ & $.34 * *$ & $.43 * *$ & $.28 * *$ & $.78 * *$ & 1 & & \\
\hline 9. Affective commitment & 3.93 & .75 & $.35 * *$ & $-.37 * *$ & $.39 * *$ & $.37 * *$ & $.41 * *$ & $.21 * *$ & $.40 * *$ & $.50 * *$ & 1 & \\
\hline 10. Job satisfaction & 3.96 & .77 & $.47 * *$ & $-.33 * *$ & $.45^{* *}$ & $.39 * *$ & $.49 * *$ & $.35 * *$ & $.40 * *$ & $.52 * *$ & $.69 * *$ & 1 \\
\hline
\end{tabular}

$* p<.05, * * p<.01$

First to test the mediating role of 'task specific strategy on 'goal clarity', 'tangible rewards' relation we conducted three step regression analyses as suggested by Baron and Kenny (1986). Even though correlation analyses indicated all variables were significantly related, 'task specific strategy' was found to be insignificant when regressed with 'goal clarity' on 'tangible rewards'. Therefore we could not find the mediating role of 'specific strategy' in this study. 'Tangible rewards' was explained by 'goal clarity' directly, not indirectly through 'task specific strategy'.

Table 4: Mediation Test for Task Specific Strategy

Step 1:

\begin{tabular}{lccccccccc} 
Independent Variable & $\boldsymbol{\beta}$ & Std. error & Std. $\boldsymbol{\beta}$ & $\boldsymbol{t}$ & $\boldsymbol{P}$ & $\boldsymbol{R}$ & $\boldsymbol{R}^{2}$ & $\boldsymbol{F}$ & $\boldsymbol{p}$ \\
\hline Goal Clarity & .61 & .09 & .44 & 7.23 & .00 & .44 & .20 & 52.24 & .00
\end{tabular}

Dependent Variable: Tangible rewards

Step 2:

\begin{tabular}{lccccccccc} 
Independent Variable & $\boldsymbol{\beta}$ & Std. error & Std. $\boldsymbol{\beta}$ & $\boldsymbol{t}$ & $\boldsymbol{P}$ & $\boldsymbol{R}$ & $\boldsymbol{R}^{\mathbf{2}}$ & $\boldsymbol{F}$ \\
\hline Goal Clarity & .30 & .05 & .36 & 5.63 & .00 & .36 & .13 & 31.71 & .00
\end{tabular}

Dependent Variable: Task specific strategy

Step 3:

Independent Variables

Goal Clarity

Task specific strategy

$\begin{array}{ccc}\boldsymbol{\beta} & \text { Std. error } & \text { Std } \\ .56 & .09\end{array}$

Dependent Variable: Tangible rewards

Than we tested the moderating role of 'supervisory support', 'performance appraisal process', 'organizational facilitation of goal achievement', 'dysfunctional effects of goals' and 'self-efficacy on 'goal clarity', 'tangible rewards' relation.

The results revealed that 'tangible rewards' were explained by the main effects of 'goal clarity', 'organizational facilitation of goal achievement', 'self-efficacy' and the interaction effects of 'performance appraisal process' and 'organizational facilitation of goal achievement'. Theoretical model on the moderation effect were partially supported. 'Supervisory 
support' and 'dysfunctional effects of goals' did not have significant effect on 'tangible rewards' as theorized. 'Performance appraisal process' had only interaction effect whereas 'organizational facilitation of goal achievement' had both main and interaction effect and 'self-efficacy' had only main effect on 'tangible rewards'. However as 'goal clarity' was significant, all the interactions were partial and the model explained only $30 \%$ of change in the 'tangible rewards'.

Table 5: Moderation Test Result

\begin{tabular}{|c|c|c|c|c|c|c|c|c|}
\hline Independent Variables & $\beta$ & Std. $\beta$ & $t$ & $R$ & $R^{2}$ & $F$ & $\Delta R^{2}$ & $\Delta F$ \\
\hline \multicolumn{9}{|l|}{ Step 1} \\
\hline Goal Clarity & .61 & .44 & $7.23 * *$ & .44 & .20 & $52.24 * *$ & .20 & $52.24 * *$ \\
\hline \multicolumn{9}{|l|}{ Step 2} \\
\hline Goal Clarity & .37 & .26 & $3.13^{* *}$ & \multirow{6}{*}{.51} & \multirow{6}{*}{.26} & \multirow{6}{*}{$12.25 * *$} & \multirow{6}{*}{.06} & \multirow{6}{*}{$3.62^{* *}$} \\
\hline Supervisory support & -.05 & -.04 & -.57 & & & & & \\
\hline Performance appraisal & .03 & .02 & .27 & & & & & \\
\hline Organizational facilitation & .44 & .28 & $3.82 * *$ & & & & & \\
\hline Dysfunctional effects & .06 & .04 & .65 & & & & & \\
\hline Self-efficacy & .17 & .09 & 1.35 & & & & & \\
\hline \multicolumn{9}{|l|}{ Step 3} \\
\hline Goal Clarity & .31 & .22 & $2.55^{*}$ & \multirow{11}{*}{.55} & \multirow{11}{*}{.30} & \multirow{11}{*}{$8.02 * *$} & \multirow{11}{*}{.04} & \multirow{11}{*}{$2.44^{*}$} \\
\hline Supervisory support & .01 & .01 & .10 & & & & & \\
\hline Performance appraisal & -.03 & -.02 & -.24 & & & & & \\
\hline Organizational facilitation & .30 & .19 & $2.49 *$ & & & & & \\
\hline Dysfunctional effects & .11 & .08 & 1.11 & & & & & \\
\hline Self-efficacy & .31 & .17 & $2.30 *$ & & & & & \\
\hline Goal Clarity X Supervisory support & .09 & .10 & 1.17 & & & & & \\
\hline Goal Clarity X Performance appraisal & -.13 & -.16 & $-2.23^{*}$ & & & & & \\
\hline Goal Clarity X Organizational facilitation & -.16 & -.18 & $-2.39 *$ & & & & & \\
\hline Goal Clarity X Dysfunctional effects & .01 & .01 & .16 & & & & & \\
\hline Goal Clarity X Self-efficacy & .11 & .11 & 1.50 & & & & & \\
\hline
\end{tabular}

Dependent variable: Tangible rewards

$* p<.05, * * p<.01$

Lastly, we conducted three step regression analyses to test the mediating role of 'job satisfaction' on 'tangible rewards' 'affective commitment' relation. Results indicated that 'job satisfaction' was a full mediator and 'tangible rewards' explained 'affective commitment' indirectly through 'job satisfaction' (See Table 6). Sobel test also supported the finding (Sobel test $=4.69, p=.00$ ).

Table 6: Mediation Test for Job Satisfaction On Tangible Rewards Affective Commitment Relation

\begin{tabular}{|c|c|c|c|c|c|c|c|c|c|}
\hline $\begin{array}{l}\text { Step 1: } \\
\text { Independent Variable }\end{array}$ & $\beta$ & Std. error & Std. $\beta$ & $\boldsymbol{t}$ & $P$ & $\boldsymbol{R}$ & $R^{2}$ & $\boldsymbol{F}$ & $p$ \\
\hline Tangible rewards & .15 & .05 & .21 & 3.19 & .00 & .21 & .05 & 10.15 & .00 \\
\hline \multicolumn{10}{|c|}{ Dependent Variable: Affective commitment } \\
\hline $\begin{array}{l}\text { Step 2: } \\
\text { Independent Variable }\end{array}$ & $\beta$ & Std. error & Std. $\beta$ & $t$ & $p$ & $\boldsymbol{R}$ & $R^{2}$ & $\boldsymbol{F}$ & $p$ \\
\hline Tangible rewards & .25 & .05 & .35 & 5.50 & .00 & .35 & .12 & 30.21 & .00 \\
\hline \multicolumn{10}{|c|}{ Dependent Variable: Job satisfaction } \\
\hline $\begin{array}{l}\text { Step 3: } \\
\text { Independent Variables }\end{array}$ & \multicolumn{9}{|c|}{ Step 3: } \\
\hline $\begin{array}{l}\text { Tangible rewards } \\
\text { Job satisfaction }\end{array}$ & $\begin{array}{l}-.02 \\
.68\end{array}$ & $\begin{array}{l}.04 \\
.05\end{array}$ & $\begin{array}{l}-.03 \\
.70\end{array}$ & $\begin{array}{r}-.61 \\
13.18\end{array}$ & $\begin{array}{l}.54 \\
.00\end{array}$ & .69 & .47 & 96.03 & .00 \\
\hline
\end{tabular}

Dependent Variable: Affective commitment

\section{CONCLUSION}

The purpose of this study was to empirically test the goal theory model and to explain organizational commitment using this model. An instrument originally developed by Locke and Latham was utilized with this purpose. Exploratory factor analysis result revealed that five demand variables which measured goal specificity and level of difficulty merged into just one variable, goal clarity. All the other variables were retained as proposed by authors even though some items were deleted. Therefore we can say the concepts existed in our study. Only demand variables are not as detailed as Locke and Latham conceptualized. Actually this seems meaningful when the items are reviewed. Items measuring these variables which are also called core goal variables, they were quite similar to each other and it seems hard to differentiate between 
them. Later when we tested the mediating role of 'task specific strategy on 'goal clarity', 'tangible rewards' relation no significant mediation effect is found, which is contradictory to literature. For this sample employees did not need a strategy as long as their goals were clear they performed and received their rewards. The moderating role of 'supervisory support', 'performance appraisal process', 'organizational facilitation of goal achievement', 'dysfunctional effects of goals' and 'selfefficacy on 'goal clarity', 'tangible rewards' relations were partially supported. And interestingly 'self-efficacy' had only main effect on 'tangible rewards'. Lastly, the mediating role of 'job satisfaction' on 'tangible rewards' 'affective commitment' relation was fully supported indicating that 'job satisfaction' was a full mediator and 'tangible rewards' explained 'affective commitment' indirectly through 'job satisfaction'. Therefore, our study showed that the empirical test of goal setting theory and also high performance cycle is partially supported. Even though goal clarity explains tangible rewards and it further explains job satisfaction which mediates affective commitment, other goal theory specific variables' mediating ad moderating roles were not exactly as theoretically conceptualized. Naturally generalizability of this findings are limited with this sample and further study with higher sample size is needed. Also one other limitation was performance was not measured. It was excluded from the model since performance cannot be obtained from employees directly and we did not have a chance to get performance data from the organization. In the future including performance in the research model will give more insights about the theory.

\section{REFERENCES}

Allen, N. J., \& Meyer, J. P. (1990). The measurement and antecedents of affective, continuance and normative commitment to the organization. Journal of Occupational Psychology, vol. 63, p. 1-18.

Bandura, A. (2011). On the functional properties of perceived self-efficacy revisited. Journal of Management. vol. 38, no.1, p. 9-44.

Baron, R. M., Kenny, D. A. (1986). The moderator-mediator variable distinction in social psychological research: Conceptual, strategic, and statistical considerations. Journal of Personality and Social Psychology, vol. 51, p. 1173-1182.

Borgogni L. \& Dello Russo S. (2012). A quantitative analysis of the High Performance Cycle in Italy. In E. A. Locke \& G. P. Latham (Eds.), New Developments in Goal Setting and Task Performance (p. 270-283). New York: Routledge.

Chen, G., Gully, S. M., \& Eden, D. (2001). Validation of a new general self-efficacy scale. Organizational Research Methods, vol. 4, p. 62-83.

Earley, P., \& Perry, B. (1987). Work plan availability and performance: An assessment of task strategy priming on subsequent task completion. Organizational Behavior and Human Development Processes, vol. 39, p. 279-302.

Kian, T., Yusoff, W., Rajah S. (2014). Job satisfaction and motivation: what are the difference among these two? European Journal of Business and Social Sciences, vol. 3, no. 2, p 94-102.

Latham, G. P., \& Locke, E. A. (2007). New developments in and directions for goal setting. European Psychologist, 12, 290-300.

Lee, C., Bobko, P., Early, P.C., \& Locke, E.A. (1991). An empirical analysis of a goal setting questionnaire. Journal of Organizational Behavior. vol. 12. p. 467-482.

Locke, E. \& Latham, G. (2006). New directions in goal-setting theory, Association for Psychological Science, vol. 15, no. 5, p. $265-268$.

Locke, E. A., \& Latham, G. P. (2002). Building a practically useful theory of goal setting and task motivation. American Psychologist, vol. 57, no. 9, p. 705-717.

Lunenburg F. (2011). Goal-setting theory of motivation, International Journal of Management, Business, and Administration vol. 15, p. 1-6.

Seijts, G.H., \& Latham, G.P. (2001). The effect of learning, outcome, and proximal goals on a moderately complex task. Journal of Organizational Behavior, vol. 22, p. 291-307.

Stecher, D. \& Rosse, J. (2007). Understanding reactions to workplace injustice through process theories of motivation, Journal of Management Education Vol. 31, p. 777-796. 